\title{
Gastric Villous Adenoma
}

National Cancer Institute

\section{Source}

National Cancer Institute. Gastric Villous Adenoma. NCI Thesaurus. Code C7038.

An intestinal-type adenomatous polyp that arises from the stomach. It is characterized by the presence of a villous architectural pattern. 